\title{
Cuba pledges 165 health workers to treat Ebola patients in Sierra Leone
}

\author{
Anne Gulland \\ London
}

The World Health Organization's director general, Margaret Chan, has welcomed the Cuban government's offer of 165 nurses and doctors to join the medical response to the outbreak of Ebola virus disease, while reiterating the desperate need for health staff.

In a joint press conference with Chan, Cuba's health minister, Roberto Morales Ojeda, said that 62 doctors and 103 nurses, all experienced in foreign medical missions, would be travelling to Sierra Leone at the beginning of October to help in the worst ever outbreak of Ebola virus disease.

Chan thanked the Cuban government for its "generosity and solidarity" but said that in the three worst affected countries-Sierra Leone, Liberia, and Guinea — the outbreak was moving faster than the government and international partners could control it. In Liberia recently 70 patients turned up to be treated in a new healthcare facility for 30 patients, said Chan. She added that "today there is not one single bed" in the whole of Liberia for the treatment of patients with the disease.

Figures released by WHO on 12 September put the number of cases in west Africa at 4784, with more than 2400 deaths. However, that figure is likely to be an underestimate.

Chan said, "Our response is running short of nearly everything: from PPE [personal protection equipment], body bags, to mobile laboratories, to isolation wards. But the thing we need most of all is people-healthcare workers."

Chan and the director general of the United Nations, Ban $\mathrm{Ki}$-moon, have been talking to world leaders, and they are hopeful that the United Kingdom, the United States, France, South Africa, and China will provide more help. However, the offer of workers from Cuba is the largest to date. China already has medical teams in the three worst affected countries, and "they are prepared to do more," said Chan.

Meanwhile USAID, the US government agency providing humanitarian assistance, has announced a recruitment drive for healthcare workers on its website (www.usaid.gov/ebola/ volunteers).
Chan said she could not put an exact figure on the number of doctors and nurses needed, as this depends on how the epidemic evolves, but 500 to 600 doctors and more than 1000 healthcare workers are needed to maintain the existing treatment centres. WHO has deployed 200 experts but does not know how many healthcare workers are currently working in the affected countries.

The ratio of foreign to local workers should be around 80:20, she said, and the World Bank is providing financial support to ensure that local workers are paid and provided with hazard incentives and insurance packages.

Earlier this week the UK Department for International Development announced that it was building a 62 bed treatment centre in Sierra Leone, which would be operated by military engineers and medical staff. However, the centre will take eight weeks to build. The House of Commons International Development Committee criticised the UK government for focusing too much of its aid money on organisations such as the GAVI Alliance, which deliver "quick wins" in the form of childhood vaccination campaigns. The committee's chair, Malcolm Bruce, said that the Ebola epidemic was an "avoidable tragedy" and a consequence of a weak health system.

"To prevent similar tragedies in the future it is essential that DFID [the Department for International Development] places a clear priority on health systems strengthening and is vocal internationally to persuade other donors to follow its lead," he said.

thebmj.com News: Trial of Ebola virus vaccine is due to start next week (BMJ 2014;349:g5562, doi:10.1136/bmj.g5562); News: First Ebola treatment is approved by WHO (2014;349:g5539, doi:10.1136/bmj. g5539); Feature: Ebola: an opportunity for a clinical trial? (2014;349:g4997, doi:10.1136/bmj.g4997) Views: Courage is treating patients with Ebola (2014;349:g4987, doi:10.1136/bmj.g4987) 